\title{
Unusual C,O-Fused Glycosylapigenins from Serjania marginata Leaves
}

\author{
Silvia C. Heredia-Vieira, ${ }^{\ddagger}$ Ana M. Simonet, ${ }^{\dagger}$ Wagner Vilegas, ${ }^{\S}$ and Francisco A. Macías ${ }^{* \dagger}$ \\ ${ }^{\dagger}$ Grupo de Alelopatía, Departamento de Química Orgánica, Instituto de Biomoléculas (INBIO), Facultad de Ciencias, Universidad de \\ Cádiz, C/República Saharaui, 7, 11510 Puerto Real (Cádiz), Spain \\ ${ }^{\ddagger}$ Faculty of Pharmaceutical Sciences, UNESP, Universidade Estadual Paulista, , Rodovia Araraquara-Jau, Km 1, 14801-902, Araraquara, \\ São Paulo, Brazil \\ ${ }^{\S}$ UNESP, Universidade Estadual Paulista, Coastal Campus of São Vicente, Praça Infante Dom Henrique, s/n, 11330-900, São Vicente, \\ São Paulo, Brazil
}

\section{Supporting Information}

ABSTRACT: A phytochemical study of a Serjania marginata leaf extract with antiulcer activity afforded 15 compounds, including the new 3-O- $\alpha$-L-arabinopyranosyl $(1 \rightarrow 3)-\alpha$-Lrhamnopyranosyl $(1 \rightarrow 2)[\beta$-D-glucopyranosyl $(1 \rightarrow 4)]-\alpha$-Larabinopyranosyloleanolic acid (1) and 7,5"-anhydroapigenin 8$C$ - $\alpha$-(2,6-dideoxy-5-hydroxy-ribo-hexopyranosyl)-4'-O- $\beta$-D-glucopyranoside (4). The structures of the new compounds were determined by spectroscopic analysis, including $1 \mathrm{D}$ and $2 \mathrm{D}$ NMR techniques, mass spectrometry, and chemical methods. Compound 4 is a $C$-hexopyranosylapigenin with an unusual cyclic ether linkage between C-5" and C-7 of apigenin. The isolated proanthocyanidins have high antioxidant activities,
gastroprotective effect of the extract.
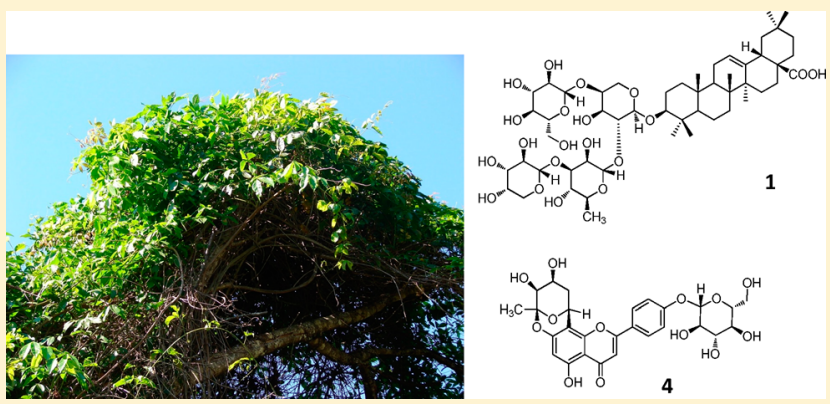

and these compounds are probably responsible for the
$\mathrm{T}$ he Sapindaceae family is widely distributed in Brazil, where there are two major biogeographic formations, namely, Cerrado and Pantanal. ${ }^{1}$ Sapindaceae species have been investigated in relation to their therapeutic properties based on traditional knowledge. Plants are a rich source of saponins, ${ }^{2}$ flavonoids, proanthocyanidins, isoprenoids, polyphenols, triterpenoids, diterpenoids, lecithin, and hydrogels. ${ }^{3,4}$ The Serjania genus belongs to the Sapindaceae family, and it occurs in tropical and subtropical regions, with 226 species that are mostly lianas. ${ }^{5}$ Crude extracts of these plants showed diverse biological activities, including anti-inflammatory, ${ }^{6}$ antioxidant, antibacterial, ${ }^{4}$ and antiulcer ${ }^{7}$ in Serjania erecta; antiprotozoal, ${ }^{8}$ larvicidal, ${ }^{9}$ antibacterial, ${ }^{3}$ and anti-inflammatory ${ }^{10}$ in S. lethalis; molluscicidal and antifungal ${ }^{11}$ in S. triquetra; antioxidant ${ }^{12}$ in $S$. glabrata; trypanocidal ${ }^{13}$ in S. yucatanensis; and antiulcer and antispasmodic $^{14}$ in S. caracasana.

Only a few studies have been carried out on the chemical constituents of the Serjania genus. Epicatechin, kaempferol, kaempferol-3-O- $\alpha$-L-rhamnopyranoside, kaempferol-3-O- $\alpha$-Lrhamnopyranosyl $(1 \rightarrow 6)$ - $\beta$-D-glucopyranoside, kaempferol-3,7di-O- $\alpha$-L-rhamnopyranoside, vitexin, and isovitexin were isolated from $S$. erecta extracts. ${ }^{4}$ The saponins serjanosides A, $\mathrm{B}$, and $\mathrm{C}$, with oleanolic acid as the sapogenin, were isolated from the methanol extract of S. lethalis. ${ }^{19}$ Hydrolysis of the methanol extract of the aerial parts of $S$. triquetra afforded the sapogenins $11 \alpha$-hydroperoxyhederagenin, stigmasterol, oleanolic acid, hederagenin, and morolic acid. ${ }^{16}$ The saponins salzmannianosides $A$ and $B$, pulsatilla saponin $D$, and hederacolchiside $A_{1}$ were isolated from the methanol extract of $S$. salzmanniana stems. ${ }^{11}$

A wide range of pharmacological activities have been described for Serjania extracts, but only a few phytochemical studies on these species have been reported. The juice from the leaves of S. marginata, which is native to Paraguay, Bolivia, Argentina, and Brazil, where it is known as "cipó-uva" and "cipó-timbó", is employed in folk medicine for internal use against stomach pains. A $70 \%$ ethanol extract of S. marginata leaves was studied to assess the antiulcerogenic activity in models of acute gastric ulcer in rodents (ethanol and indomethacin), and the results confirmed that the S. marginata extract possesses antiulcer activity. ${ }^{17}$

A wide plant biodiversity, in addition to social contrasts, makes the use of medicinal plants a common practice in Brazil, where it is estimated that $82 \%$ of the population use products based on medicinal plants. However, only $8 \%$ of the species have been studied in research on bioactive compounds. ${ }^{18}$ The Biota/FAPESP research program for the sustainable use of Brazilian biodiversity (www.biota.org.br) includes the search for potential medicinal plants for future use in the Brazilian Public Health System (SUS). Preliminary studies on the antiulcerogenic effects of $S$. marginata extracts were promising, and it is

Received: September 12, 2014

Published: December 17, 2014 
important to ascertain the chemical composition of these extracts. Herein a chemical analysis of the ethanolic extract of $S$. marginata leaves, as well as a correlation between isolated compounds and antioxidant activity, is reported.

\section{RESULTS AND DISCUSSION}

The $70 \%$ ethanolic extract from the leaves of $S$. marginata yielded 15 pure compounds: 3-O-D- $\beta$-glucopyranosylsitoster$\mathrm{ol}^{19}{ }^{19}$ the saponins pulsatilla saponin $\mathrm{D},{ }^{20}$ hederacolchiside $\mathrm{A}_{1}{ }^{21}$ salzmannianoside $\mathrm{B},{ }^{11}$ and compound $\mathbf{1}$, the flavonoids quercetin 3-O- $\alpha$-L-rhamnopyranoside, ${ }^{22}$ epicatechin, ${ }^{23}$ cassiaoccidentalin A (2), ${ }^{24}$ tetrastigma B (3), ${ }^{25}$ apigenin $6-C-\beta$ boivinopyranosyl-7-O- $\beta$-D-glucopyranoside, ${ }^{26}$ apigenin $6-C$ - $[2-$ $O$ - $\alpha$-L-rhamnopyranosyl $(1 \rightarrow 2)]-\beta$-D-xylopyranoside, ${ }^{27}$ and compound 4 , and the proanthocyanidins proanthocyanidins A-1 and A-2 ${ }^{28}$ and cinnamtannin B-1 (Figure 1). ${ }^{29}$ The
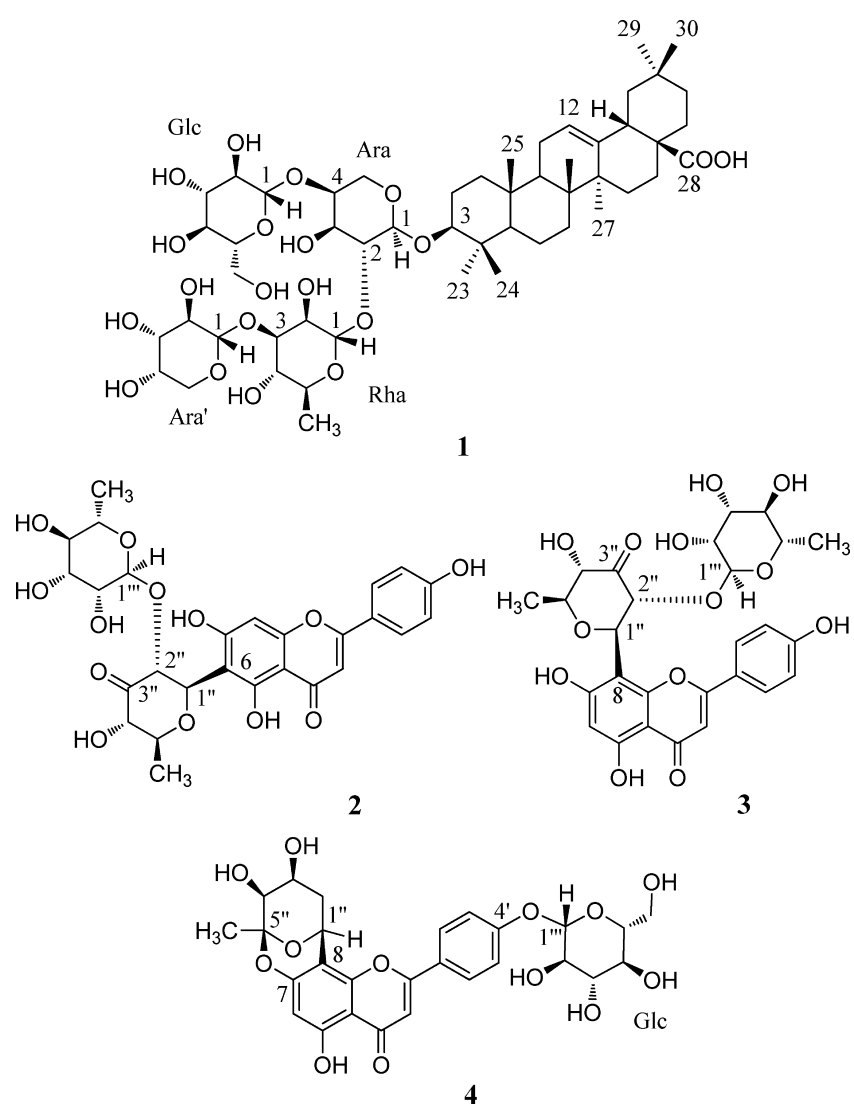

Figure 1. Structures of serjanioside D (1), cassiaoccidentalin A (2), tetrastigma B (3), and serjanione A (4).

absolute configurations of the sugar moieties were verified by measurement of the optical rotation of each purified sugar after acid hydrolysis of fractions $\mathrm{A}$ and $\mathrm{B}$. The configurations were $\mathrm{D}$ for the glucose and $\mathrm{L}$ for the rhamnose and arabinose sugars.

Compound 1 was isolated as the major component from the saponin fraction, and this compound gave a quasi-molecular ion peak at $m / z 1027.5475[\mathrm{M}-\mathrm{H}]^{-}($calcd 1027.5478$)$ in the HRESIMS, which, in conjunction with the ${ }^{13} \mathrm{C}$ NMR data, is consistent with the molecular formula $\mathrm{C}_{52} \mathrm{H}_{84} \mathrm{O}_{20}$. The NMR features of compound $\mathbf{1}$ (Table 1) had similar characteristics to those of previously described saponins from the genus Serjania. ${ }^{11}$ Analysis of the ${ }^{13} \mathrm{C}$ NMR chemical shifts of the shielded signals suggests that oleanolic acid is the aglycone.
This assertion was confirmed by the ${ }^{1} \mathrm{H}-{ }^{1} \mathrm{H}$ COSY, TOCSY, ROESY, HSQC, and HMBC data.

Concerning the carbohydrate portion of compound 1 , the ${ }^{1} \mathrm{H}$ NMR spectrum contained signals for four anomeric protons at $\delta 6.26,5.30,5.12$, and 4.74 (Table 1). These protons showed correlations in the HSQC spectrum with carbon signals at $\delta$ $101.4,107.4,106.6$, and 105.0, respectively. Individual sugar units were identified by $1 \mathrm{D}$-TOCSY and 1D-ROESY experiments involving selective excitation of each anomeric proton. ${ }^{30}$ Selective 1D-TOCSY experiments on the signal at $\delta 5.12$ showed a typical spin system of a $\beta$-glucopyranosyl moiety. The NOE associations observed in the 1D-ROESY experiment between the anomeric proton and $\mathrm{H}-3$ and $\mathrm{H}-5$ were consistent with the structure of this sugar. The results of 1D-TOCSY experiments on the anomeric signals at $\delta 6.26$ (brs) and 1.55 (d, $6.1 \mathrm{~Hz}$ ) were consistent with a rhamnopyranosyl unit. ${ }^{31}$ The selective excitation of the methyl group indicated axial-axial relationships between $\mathrm{H}-5 / \mathrm{H}-4$ and $\mathrm{H}-4 / \mathrm{H}-3$. The absence of correlations between the anomeric proton and H-3 and H-5 in the 1D-ROESY spectrum confirmed the identification as an $\alpha$ rhamnopyranosyl moiety. Likewise, anomeric signals at $\delta 5.30$ and 4.74 showed TOCSY patterns reminiscent of the spin system of two arabinopyranosyl units (Figure 2), in which the coupling constants are consistent with trans-diaxial $\mathrm{H}-1 / \mathrm{H}-2$ and $\mathrm{H}-2 / \mathrm{H}-3$ arrangements. The $J_{3,4}=3.6 \mathrm{~Hz}$ magnitude of $\mathrm{H}$ $4_{\mathrm{Ara}^{\prime}}(\delta 4.17 \mathrm{dd})$ indicated the equatorial position of $\mathrm{H}-4$. This arrangement was supported by the 1D-ROESY spectra of both anomeric signals, which showed correlations with $\mathrm{H}-3$ and $\mathrm{H}$ $5_{\mathrm{ax}}$. Finally, an HSQC experiment unambiguously showed the complete correlations of the proton and carbon signals of the tetrasaccharide portion.

The connection between each of the sugar units and the aglycone was elucidated by HMBC/ROESY correlations between anomeric protons and the corresponding carbon/ proton signals of the positions in which the sugars were $\mathrm{O}$ bonded. Long-range $\mathrm{HMBC} / \mathrm{ROESY}$ correlations were observed between $\mathrm{H}-1_{\mathrm{Ara}^{\prime}}\left(\delta\right.$ 5.30) and C-3 $\mathrm{Rha}\left(\delta\right.$ 82.9)/H-3 $3_{\mathrm{Rha}}(\delta$ $4.72), \mathrm{H}-1_{\mathrm{Rha}}(\delta 6.26)$ and C-2 $\mathrm{Ara}(\delta 75.8) / \mathrm{H}-2_{\mathrm{Ara}}(\delta 4.51), \mathrm{H}-$ $1_{\mathrm{Glc}}\left(\delta\right.$ 5.12) and C-4 $4_{\text {Ara }}(\delta 80.1) / \mathrm{H}-4_{\text {Ara }}\left(\delta\right.$ 4.21), H-1 $1_{\text {Ara }}(\delta$ $4.74)$, and C-3 $(\delta 88.7) / \mathrm{H}-3$ ( $\delta 3.25)$ of oleanolic acid. These observations provided evidence of the same glycosidic chain as reported for salzmannianoside $\mathrm{B},{ }^{11}$ which was isolated from $S$. salzmanniana and gave similar NMR data for this portion of the molecule (Table 2). The configurations were $\mathrm{D}$ for the glucose and $\mathrm{L}$ for the rhamnose and arabinose sugars based on the hydrolysis of the saponins fraction (A).

The structure of compound 1 was therefore 3-O- $\alpha-\mathrm{L}-$ arabinopyranosyl $(1 \rightarrow 3)$ - $\alpha$-L-rhamnopyranosyl $(1 \rightarrow 2)[\beta$-Dglucopyranosyl $(1 \rightarrow 4)]$ - $\alpha$-L-arabinopyranosyloleanolic acid (Figure 1). A literature review showed that 1 was reported earlier as raddeanoside $\mathrm{R}_{23}$ by $\mathrm{Fan}$ and co-workers from the rhizome of Anemone raddeana. ${ }^{32}$ Comparison of the reported NMR data was consistent with most of the signals observed for compound 1, but those of the terminal arabinopyranoside differed significantly (Table 2). The NMR data assigned to its anomeric position were quite different. However, comparison of the chemical shifts observed for an isomer of compound 1 described by Hai et al. ${ }^{33}$ from Clematis argentilucida, which has a ribopyranosyl instead of a terminal arabinopyranosyl moiety, indicated that the compound isolated by Fan et al. from Anemone raddeana contained a ribose unit (Table 2), and, consequently, the reported structure should be revised. It is 
Table 1. ${ }^{1} \mathrm{H}$ NMR (600 MHz) and ${ }^{13} \mathrm{C}$ NMR (125 MHz) Spectroscopic Data for Serjanoside D (1) in Pyridine- $d_{5}$

\begin{tabular}{|c|c|c|c|c|c|c|c|}
\hline position & $\delta_{\mathrm{C}}$ & & $\delta_{\mathrm{H}}(J$ in $\mathrm{Hz})$ & position & $\delta_{\mathrm{C}}$ & & $\delta_{\mathrm{H}}(J$ in $\mathrm{Hz})$ \\
\hline 1 & 38.9 & $\mathrm{CH}_{2}$ & $\operatorname{ax} 0.91 ;^{a}$ eq $1.45^{a}$ & Ara & & & \\
\hline 2 & 26.7 & $\mathrm{CH}_{2}$ & ax $1.80 ;^{a}$ eq $2.06^{a}$ & 1 & 105.1, & $\mathrm{CH}$ & $4.74, \mathrm{~d}(6.6)$ \\
\hline 3 & 88.7 & $\mathrm{CH}$ & 3.25 , dd $(11.8,4.3)$ & 2 & 75.8 & $\mathrm{CH}$ & $4.51, \mathrm{dd}(6.6,7.8)$ \\
\hline 4 & 39.5 & $\mathrm{C}$ & & 3 & 74.7 & $\mathrm{CH}$ & $4.19^{a}$ \\
\hline 5 & 56.0 & $\mathrm{CH}$ & 0.79, brd $(12.0)$ & 4 & 80.1, & $\mathrm{CH}$ & 4.21 , brs \\
\hline 6 & 18.5 & $\mathrm{CH}_{2}$ & $1.49 j^{a} 1.27^{a}$ & 5 & 65.2, & $\mathrm{CH}_{2}$ & ax $4.38 ;^{a}$ eq 3.74 , brd (10.6) \\
\hline 7 & 33.2 & $\mathrm{CH}_{2}$ & $1.46 ;^{a} 1.26^{a}$ & & & & \\
\hline 8 & 39.7 & $\mathrm{C}$ & & Rha & & & \\
\hline 9 & 48.0 & $\mathrm{CH}$ & $1.64, \mathrm{t}(8.8)$ & 1 & 101.4, & $\mathrm{CH}$ & 6.26 , brs \\
\hline 10 & 37.0 & $\mathrm{C}$ & & 2 & 71.8 & $\mathrm{CH}$ & 4.92 , brs \\
\hline 11 & 23.6 & $\mathrm{CH}_{2}$ & 1.89, dd $(8.8,3.2)$ & 3 & 82.9, & $\mathrm{CH}$ & 4.72 , dd $(9.6,3.2)$ \\
\hline 12 & 122.5 & $\mathrm{CH}$ & $5.46, \mathrm{t}(3.2)$ & 4 & 73.0 & $\mathrm{CH}$ & 4.45 , ddd $(9.6,9.5,2.5)$ \\
\hline 13 & 144.8 & $\mathrm{C}$ & & 5 & 69.5 & $\mathrm{CH}$ & $4.67, \mathrm{dq}(9.5,6.1)$ \\
\hline 14 & 42.1 & $\mathrm{C}$ & & 6 & 18.5 & $\mathrm{CH}_{3}$ & $1.55, \mathrm{~d}(6.1)$ \\
\hline 15 & 28.3 & $\mathrm{CH}_{2}$ & ax 2.16 , brdd $(13.1,13.1)$; eq $1.17^{a}$ & & & & \\
\hline 16 & 23.6, & $\mathrm{CH}_{2}$ & ax 2.10 , brdd $(13.1,12.1)$; eq 1.95 , brd (12.1) & Glc & & & \\
\hline 17 & 46.6, & $\mathrm{C}$ & & 1 & 106.7, & $\mathrm{CH}$ & $5.12, \mathrm{~d}(7.9)$ \\
\hline 18 & 42.0 & $\mathrm{CH}$ & 3.29, dd $(13.8,3.9)$ & 2 & 75.5 & $\mathrm{CH}$ & $4.02, \mathrm{dd}(7.9,9.0)$ \\
\hline 19 & 46.4, & $\mathrm{CH}_{2}$ & ax 1.79 , dd $(13.8,13.8)$; eq $1.27^{a}$ & 3 & 78.5 & $\mathrm{CH}$ & 4.17, dd $(9.0,9.0)$ \\
\hline 20 & 30.9 & $\mathrm{C}$ & & 4 & 71.2 & $\mathrm{CH}$ & 4.24 , dd $(9.0,9.4)$ \\
\hline 21 & 34.2 & $\mathrm{CH}_{2}$ & ax $1.43 ;^{a}$ eq $1.17^{a}$ & 5 & 78.8 & $\mathrm{CH}$ & 3.89 , ddd $(9.4 ; 4.9 ; 2.4)$ \\
\hline 22 & 33.2 & $\mathrm{CH}_{2}$ & ax $2.03 ;^{a}$ eq $1.80^{a}$ & 6 & 62.5 & $\mathrm{CH}_{2}$ & 4.50, brd $(12,2) ; 4.38$, dd $(12.2 ; 4.9)$ \\
\hline 23 & 28.2 & $\mathrm{CH}_{3}$ & $1.32, \mathrm{~s}$ & & & & \\
\hline 24 & 17.2 & $\mathrm{CH}_{3}$ & $1.15, \mathrm{~s}$ & Ara' $^{\prime}$ & & & \\
\hline 25 & 15.5 & $\mathrm{CH}_{3}$ & $0.83, \mathrm{~s}$ & 1 & 107.4, & $\mathrm{CH}$ & $5.30, \mathrm{~d}(7.2)$ \\
\hline 26 & 17.4, & $\mathrm{CH}_{3}$ & $0.99, \mathrm{~s}$ & 2 & 73.2 & $\mathrm{CH}$ & $4.53, \mathrm{dd}(7.2,8.6)$ \\
\hline 27 & 26.2 & $\mathrm{CH}_{3}$ & $1.29, \mathrm{~s}$ & 3 & 74.6, & $\mathrm{CH}$ & 4.17, dd $(8.6,3.6)$ \\
\hline 28 & 180.1, & $\mathrm{C}$ & & 4 & 69.5, & $\mathrm{CH}$ & 4.28 , brs \\
\hline 29 & 33.2 & $\mathrm{CH}_{3}$ & $0.94, \mathrm{~s}$ & 5 & 67.1, & $\mathrm{CH}_{2}$ & ax 4.32 , dd $(12.2,2.7)$; eq 3.81 \\
\hline 30 & 23.7 & $\mathrm{CH}_{3}$ & $0.99, \mathrm{~s}$ & & & & brd $(12.2)$ \\
\hline
\end{tabular}

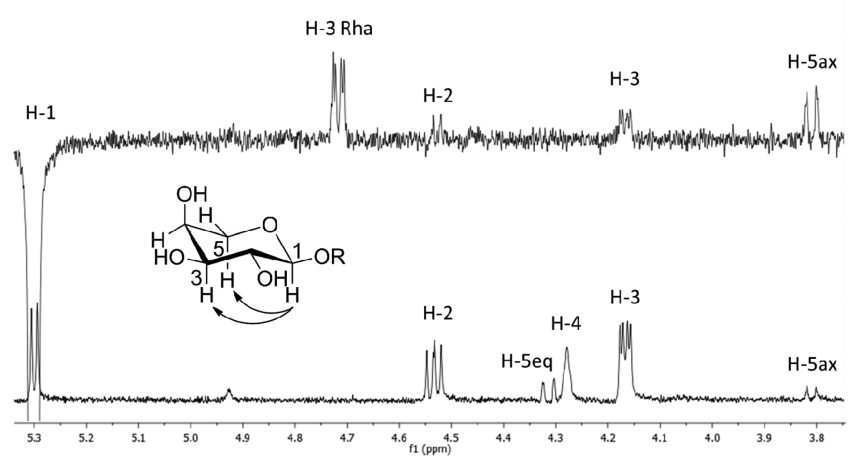

Figure 2. 1D TOCSY (bottom, $\mathrm{mix}=0.15 \mathrm{~s}$ ) and 1D ROESY (top, $\operatorname{mix}=0.2 \mathrm{~s})$ spectra obtained from the anomeric proton $(5.30 \mathrm{ppm})$ of the arabinose moiety. The arrows indicate the ROE correlations between axial protons.

interesting to note that both plants belong to the same family, Ranunculaceae, rather than the Serjania genus (Sapindaceae).

Thus, $\quad 3-O-\alpha-\mathrm{L}$ - arabinopyranosyl $(1 \rightarrow 3)-\alpha-\mathrm{L}$ rhamnopyranosyl $(1 \rightarrow 2)[\beta$-D-glucopyranosyl $(1 \rightarrow 4)]-\alpha$-Larabinopyranosyloleanolic acid is a new compound, and we propose to name it serjanoside $\mathrm{D}$.

Only the flavonoid C-glucosides, vitexin, and isovitexin have been described previously for the Serjania genus. ${ }^{4}$ In the work described here, cassiaoccidentalin A (2), tetrastigma B (3), apigenin 6 - $C$ - $\beta$-boivinopyranosyl-7- $O-\beta$-glucopyranoside, apige- nin 6-C-[2-O- $\alpha$-L-rhamnopyranosyl $(1 \rightarrow 2)]-\beta$-D-xylopyranoside, and compound 4 were isolated. The NMR signals of $C$ glycosidic flavonoids are generally doubled or broadened, an observation that is generally attributed to the presence of rotamers in solution. ${ }^{34,35}$ In addition, for cassiaoccidentalin A (2) and tetrastigma B (3) (Figure 1), a change of the multiplicity of the $\mathrm{H}-1^{\prime \prime}$ and $\mathrm{H}-2^{\prime \prime}$ resonances of 6-deoxy-ribohex-3-ulopyranose sugar was observed when the compounds were dissolved in the protic solvent $\mathrm{MeOH}-d_{4}$. The doublets at $\delta 5.21(10.0 \mathrm{~Hz})$ and $5.04(10.0 \mathrm{~Hz})$ observed in fresh $\mathrm{MeOH}-$ $d_{4}$ solution in the ${ }^{1} \mathrm{H}$ NMR spectrum of tetrastigma B (3) changed over time. The anomeric proton signal was converted to a singlet and the $\mathrm{H}-2^{\prime \prime}$ signal disappeared (Figure 3 ). The 2D-ROESY spectrum showed a correlation between $\mathrm{H}-\mathrm{1}^{\prime \prime}$ and $\mathrm{H}-5^{\prime \prime}$, indicating that epimerization had not occurred at C-1". Liu and co-workers ${ }^{36,37}$ reported that oxoglycosides showed enolization of the carbonyl group in solution. In the cases of cassiaoccidentalin A (2) and tetrastigma B (3), enolization (Figure 3) would explain the fast deuteration at C-2" and, consequently, the disappearance of the signal in the ${ }^{1} \mathrm{H}$ NMR spectrum and the simplification of the $\mathrm{H}-1^{\prime \prime}$ signal to a singlet. This behavior has not been described previously for $C$ oxoglycosidic flavones and should be taken into consideration for NMR metabolomics studies, which are usually carried out in protic solvents.

Minor compound 4 has the molecular formula $\mathrm{C}_{27} \mathrm{H}_{28} \mathrm{O}_{13}$ determined from its HRESIMS, and the ${ }^{1} \mathrm{H}$ and ${ }^{13} \mathrm{C}$ NMR spectra showed characteristic signals of a C-glycosylated 
Table 2. Chemical Shifts of the Terminal Sugar for Serjanoside D (1) and Those Reported for Salzmannianoside B, ${ }^{11}$ Raddeanoside $\mathrm{R}_{23},{ }^{32}$ and $3 \beta$ - $O$ - $\{\beta$-D-Ribopyranosyl $(1 \rightarrow 3)$ - $\alpha$-L-rhamnopyranosyl $(1 \rightarrow 2)$ - $[\beta$-D-glucopyranosyl $(1 \rightarrow 4)]-\beta$-Dxylopyranosyl $\}$ oleanolic Acid ${ }^{33}$ (Ribopyranosyl Derivative) in Pyridine- $d_{5}$

\begin{tabular}{|c|c|c|c|c|c|c|c|c|}
\hline \multirow[b]{2}{*}{ position } & \multicolumn{2}{|r|}{ compound $\mathbf{1}^{a}$} & \multicolumn{2}{|r|}{ salzmannianoside $\mathrm{B}^{b}$} & \multicolumn{2}{|c|}{ raddeanoside $\mathrm{R}_{23}{ }^{a}$} & \multicolumn{2}{|c|}{ ribopyranosyl derivative $^{b}$} \\
\hline & $\overline{\delta_{\mathrm{C}}}$ & $\delta_{\mathrm{H}}(J$ in $\mathrm{Hz})$ & $\overline{\delta_{\mathrm{C}}}$ & $\delta_{\mathrm{H}}(J$ in $\mathrm{Hz})$ & $\delta_{\mathrm{C}}$ & $\delta_{\mathrm{H}}(\mathrm{J}$ in $\mathrm{Hz})$ & $\overline{\delta_{\mathrm{C}}}$ & $\delta_{\mathrm{H}}(\mathrm{J}$ in $\mathrm{Hz})$ \\
\hline 1 & 107.4 & $5.30, \mathrm{~d}(7.2)$ & 106.8 & $5.31, \mathrm{~d}(7.2)$ & 104.8 & $5.99, \mathrm{~d}(3.6)$ & 104.7 & $5.96, \mathrm{~d}(4.2)$ \\
\hline 2 & 73.2 & 4.53 , dd $(7.2,8.6)$ & 72.6 & $4.54, \mathrm{~m}$ & 72.8 & $4.48-4.52, \mathrm{~m}$ & 72.9 & $4.32, \mathrm{~m}$ \\
\hline 3 & 74.6 & 4.17, dd $(8.6,3.6)$ & 74.0 & $4.11, \mathrm{~m}$ & 70.4 & $4.35-4.37, \mathrm{~m}$ & 68.8 & $4.50, \mathrm{~m}$ \\
\hline 4 & 69.5 & 4.28, brs & 69.0 & $4.17-4.25, \mathrm{~m}$ & 68.7 & $4.31-4.35, \mathrm{~m}$ & 70.4 & 4.17, m \\
\hline 5 & 67.1 & ax 4.32 , dd $(12.2,2.7)$; eq 3.81 , brd $(12.2)$ & 65.4 & $4.34-4.38, \mathrm{~m} ; 3.58, \mathrm{~d}(12.2)$ & 65.3 & $4.14-4.18, \mathrm{~m}$ & 65.3 & $4.35, \mathrm{~m} ; 4.17, \mathrm{~m}$ \\
\hline
\end{tabular}

${ }^{a} 600 \mathrm{MHz} .{ }^{b} 500 \mathrm{MHz}$.
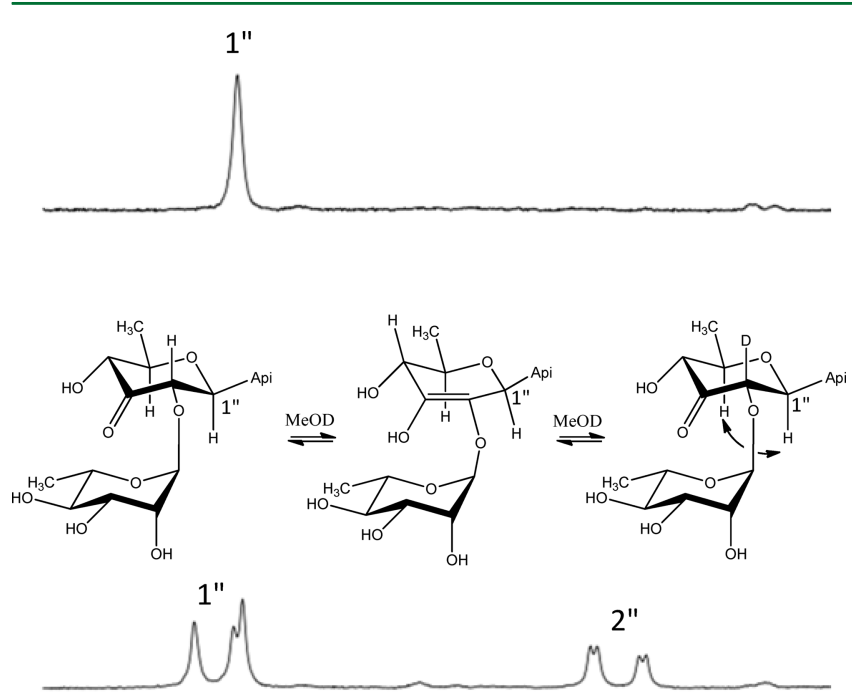

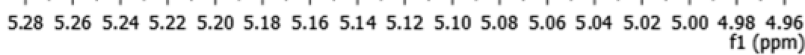

Figure 3. ${ }^{1} \mathrm{H}$ NMR spectra of fresh solution (bottom) and solution after $12 \mathrm{~h}$ (top) of tetrastigma B (3) in $\mathrm{MeOH}-d_{4}$. The modifications of $\mathrm{H}-1$ " and $\mathrm{H}-2^{\prime \prime}$ signals can be attributed to the deuteration of $\mathrm{C}-2^{\prime \prime}$ through the enolization shown. The arrows indicate the ROE correlations between protons $\mathrm{H}-\mathrm{1}^{\prime \prime}$ and $\mathrm{H}-\mathrm{5}^{\prime \prime}$.

apigenin as in the flavones described previously. Furthermore, in the ${ }^{1} \mathrm{H}$ NMR spectrum signals were observed that are consistent with two anomeric protons, $\delta 5.39 \mathrm{dd}(5.0,1.5 \mathrm{~Hz})$ and $5.04 \mathrm{~d}(7.4 \mathrm{~Hz})$, which correlate with carbon signals at $\delta$ 64.5 and 101.7 in the HSQC spectrum. These observations indicate the presence of $C$ - and $O$-glycosidic units, respectively. The MS/MS spectrum of the molecular ion showed the fragment ion peak at $m / z 399(\mathrm{M}+\mathrm{H}-162)$, corresponding to the loss of an $O$-hexosyl unit (Figure 4). The chemical shift of the corresponding signals ${ }^{38}$ and the correlation observed in the 2D-TOCSY spectrum between the anomeric proton signal and each of the hexosyl signals, including $\mathrm{H}-6,{ }^{30}$ indicates the presence of one glucose unit. The coupling constant for $\mathrm{H}-1$ is characteristic of a $\beta$-configuration.

The doublet at $\delta 7.27(2 \mathrm{H}, J=9 \mathrm{~Hz})$ corresponding to the protons $\mathrm{H}-3^{\prime} / 5^{\prime}$ of the $\mathrm{B}$ ring was deshielded, and this is consistent with glycosylation of the C-4' hydroxy group. The C-4' connection of the glucopyranosyl moiety was confirmed by the ROESY correlation observed between $\mathrm{H}$-1glc $(\delta$ 5.04) and $\mathrm{H}-3^{\prime} / 5^{\prime}$ ( $\delta$ 7.27).

In addition to the glucosyl signals, the ${ }^{1} \mathrm{H}$ NMR spectrum contained an anomeric signal at $\delta 5.39(1 \mathrm{H}, \mathrm{dd}, J=5.0 ; 1.5 \mathrm{~Hz})$ that was correlated with $\delta 64.5\left(\mathrm{C}-1^{\prime \prime}\right)$. Analysis of the 2D TOCSY and ${ }^{1} \mathrm{H}-{ }^{1} \mathrm{H}$ COSY spectra allowed the spin system for this sugar to be identified as $\left[-\mathrm{O}-\mathrm{CHR}-\mathrm{CH}_{2}-\mathrm{CHOH}-\right.$ $\mathrm{CHOH}-]$, and the following assignments were made: $\mathrm{H}-1^{\prime \prime}(\delta$ 5.39 , dd, $J=5.0 ; 1.5 \mathrm{~Hz}) ; \mathrm{H}-2^{\prime \prime}(\delta 2.48$, ddd, $14.7,5.0,3.6 \mathrm{~Hz}$ and $\delta 2.30$, ddd, $14.7,1.5,2.2 \mathrm{~Hz}) ; \mathrm{H}-3^{\prime \prime}(\delta 4.14, \mathrm{~m})$; and H-4" $(\delta 3.66, \mathrm{~d}, 4.5 \mathrm{~Hz})$, with correlations with the ${ }^{13} \mathrm{C}$ NMR signals C-1" $(\delta$ 64.5); C-2" ( $\delta 37.4)$; C-3" ( $\delta$ 67.0); and C-4" ( $\delta$ 73.6), which are consistent with a 2-deoxysugar. A three-proton singlet at $\delta 1.63$ was correlated with C-4" $(\delta 73.6)$ and the quaternary carbon, $\delta 102.4$, in the HMBC (Figure 4), which suggests a 6 "-deoxy unit and a fully substituted C-5". The pyranoside form of the sugar was determined by the correlation observed in the HMBC experiment between the anomeric proton signal $(\delta$ 5.39) and C-5" $(\delta$ 102.4). The chemical shift for $C-5$ " was consistent with its dioxygenated substitution. A natural hexopyranoside monosaccharide with $\mathrm{C}-5$ " dioxygenation could not be traced in the literature. Synthetic sugars with a $5^{\prime \prime}$-hydroxy group have been described, ${ }^{39}$ and the chemical shifts of the signals for C-5" and C- 6 " in the ${ }^{1} \mathrm{H}$ and ${ }^{13} \mathrm{C}$ NMR spectra are consistent with those of compound 4.

The coupling constants of the anomeric proton signal at $\delta$ $5.39 \mathrm{dd}(5.0,1.5 \mathrm{~Hz})$ indicate that there is no axial-axial arrangement with one of the $\mathrm{H}-2^{\prime \prime}$ protons, and we, therefore, consider that $\mathrm{H}-1^{\prime \prime}$ is $\alpha$. The 2D-ROESY spectrum shows a correlation between one of the C-2" protons ( $\delta 2.48$, ddd, 14.7, $5.0,3.6 \mathrm{~Hz})$ and $\mathrm{H}-4^{\prime \prime}(\delta 3.66, \mathrm{~d}, 4.5 \mathrm{~Hz})$, thus indicating that both are in axial positions. On the other hand, the observed coupling constants for $\mathrm{H}-2 \mathrm{ax}^{\prime \prime}, \mathrm{H}-3^{\prime \prime}$, and $\mathrm{H}-4^{\prime \prime}$ are consistent with an equatorial arrangement of $\mathrm{H}-3^{\prime \prime}$. The relative configurations deduced for $\mathrm{H}-2^{\prime \prime}, \mathrm{H}-3^{\prime \prime}$, and $\mathrm{H}-4^{\prime \prime}$ are consistent with those found in the literature. ${ }^{38,40}$ All of these values indicate the relative configuration of the sugar as shown in Figure 4, which corresponds to a $\alpha$-2,6-dideoxy-5-hydroxy-ribohexopyranosyl moiety.

The chemical shift $\left(\delta\right.$ 64.5) observed in the ${ }^{13} \mathrm{C}$ NMR spectrum for C-1" is typical of a $C$-glycosidic bond. The C-8 position for the glycosylation is proposed on the basis of the correlation in the 1D ROE spectrum (Figure 4) between $\mathrm{H}-1^{\prime \prime}$ $(\delta 5.39, \mathrm{dd}, 5.0,1.7 \mathrm{~Hz})$ and $\mathrm{H}-2^{\prime} / 6^{\prime}(\delta$ 7.93, d, $9.0 \mathrm{~Hz})$.

The molecular formula $\mathrm{C}_{27} \mathrm{H}_{28} \mathrm{O}_{13}$ is consistent with an additional unsaturation that would arise from a cyclic ether. The HMBC spectrum showed a weak correlation of C-6" $(\delta$ $1.63)$ with $\mathrm{C}-7$ ( $\delta$ 159.9), and this is consistent with a cyclic ether between C-7 and C-5". O,C-Fused glycosidic flavonoids are rare but have been described in the literature. ${ }^{41}$ The minimized structure ${ }^{42}$ showed theoretical values for coupling constants that are consistent with the experimental values (Figure 4). 


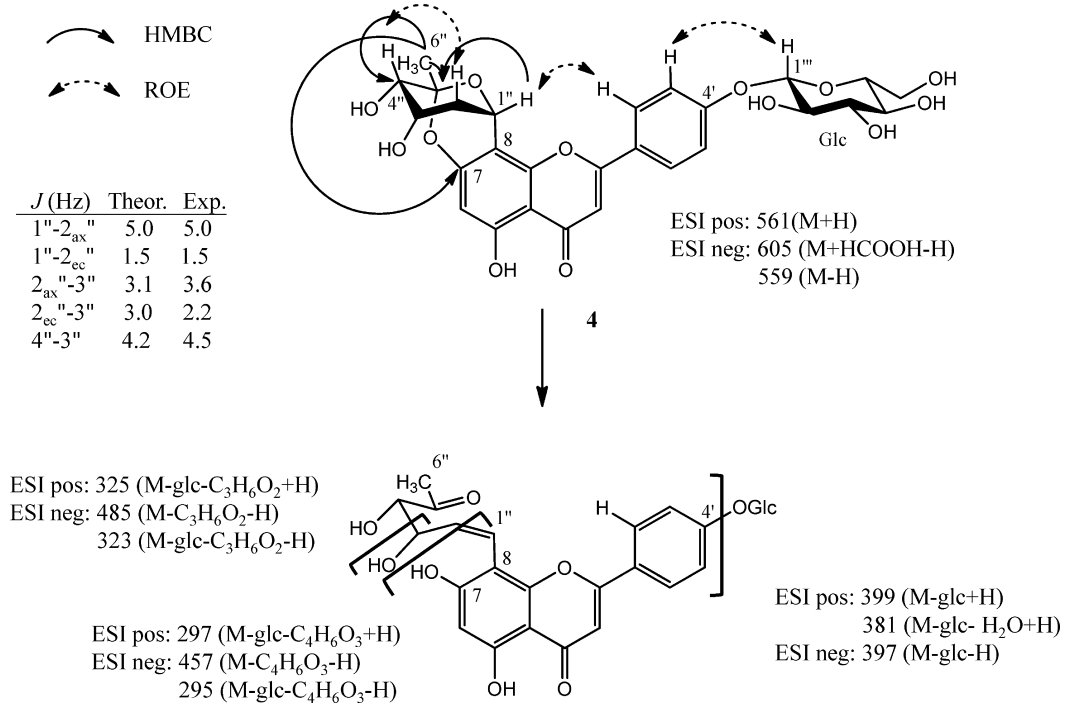

Figure 4. Selected correlation observed in the HMBC spectrum (solid arrows) and ROE correlations (dashed arrows) for compound 4. Observed coupling constants vs theoretical values for the O,C-fused glycopyranoside obtained using GMMX. ${ }^{42} \mathrm{MS} / \mathrm{MS}$ fragments shown from $m / z 561$ (ESI positive mode) and 605 (ESI negative mode).

Thus, compound 4 was identified as apigenin 7,5"-anhydro8 -C- $\alpha$-(2,6-dideoxy-5-hydroxy-ribo-hexopyranosyl)-4'-O- $\beta$-Dglucopyranoside (Figure 1). This structure has not been described previously, and we propose to name it serjanone A.

Reactive oxygen species are involved in the pathogenesis of gastric lesions, ${ }^{4,44}$ and antioxidants play an important role in protecting against such damage. It has been shown that rutin at a dose of $200 \mathrm{mg} \mathrm{kg}^{-1}$ showed a gastroprotective effect against $50 \%$ ethanol-induced ulcers, and this effect may be related to the antioxidant properties, since rutin was able to decrease the levels of lipoperoxide and increase the antioxidant activity of the enzyme GSH-Px. ${ }^{45}$ In addition, it was determined that the production of free radicals increased after ulceration induced by pylorus ligation in rats. ${ }^{46}$

Based on the information outlined above, a DPPH antioxidant activity assay was performed on the $70 \%$ ethanolic extract (EE), fractions $(\mathrm{A}-\mathrm{C})$, and selected pure compounds (Table 4). The extract (EE) showed an $\mathrm{IC}_{50}$ of $69.6 \mu \mathrm{g} \mathrm{mL}^{-1}$. The activity was higher for fraction $\mathrm{C}\left(\mathrm{IC}_{50} 42.83 \mu \mathrm{g} \mathrm{mL}^{-1}\right)$. The compounds isolated from this fraction were proanthocyanidin A-1, proanthocyanidin A-2, and cinnamtannin B-1. The antioxidant activity of these compounds, as evaluated by the DPPH assay, has been described previously. Cinnamtannin B$1,{ }^{29}$ isolated from the leaves of Ixora coccinea, showed an $\mathrm{IC}_{50}$ of $5.30 \mu \mathrm{g} \mathrm{mL}^{-1}$, and proanthocyanidins A-1 and A-2, isolated from peanut skin, showed $\mathrm{IC}_{50}$ values of 8.55 and $9.71 \mu \mathrm{g} \mathrm{mL}^{-1}$, respectively. ${ }^{47}$ In general, compounds that are capable of scavenging $50 \%$ of the DPPH radical at a concentration less than or close to $10 \mu \mathrm{g} \mathrm{mL}^{-1}$ have a strong antioxidant activity. ${ }^{48}$ On the other hand, the major flavonoids cassiaoccidentalin A (2) and tetrastigma B (3) did not show significant free radical scavenging properties at the concentrations evaluated ( 0.625 to $20 \mu \mathrm{g} \mathrm{mL}^{-1}$ ). Therefore, we concluded that proanthocyanidins are mostly responsible for the antioxidant activity of $S$. marginata, which has strong free radical scavenging properties, and probably also for the gastroprotective effect of the extract. The correlation between tannins and gastroprotective effect was described for Syzygium cumini, ${ }^{49}$ Eugenia dysenterica, ${ }^{50}$ and Mouriri pusa. ${ }^{51}$
Table 3. ${ }^{1} \mathrm{H}$ NMR (600 MHz) and ${ }^{13} \mathrm{C}$ NMR (125 MHz) Spectroscopic Data for Serjanone A (4) in MeOH- $d_{4}$

\begin{tabular}{|c|c|c|c|c|}
\hline position & \multicolumn{2}{|c|}{$\delta_{\mathrm{C}}$, type } & \multirow[t]{2}{*}{$\delta_{\mathrm{H}}(\mathrm{J}$ in $\mathrm{Hz})$} & \multirow[t]{2}{*}{$\mathrm{HMBC}$} \\
\hline 2 & 165.2, & $\mathrm{C}$ & & \\
\hline 3 & 105.3, & $\mathrm{CH}$ & $6.70, \mathrm{~s}$ & $\begin{array}{l}\text { C-2, C-4, C-10, } \\
\text { C-1 } 1^{\prime}\end{array}$ \\
\hline 4 & 184.1, & C & & \\
\hline 5 & 160.6, & $\mathrm{C}$ & & \\
\hline 6 & 100.2, & $\mathrm{CH}$ & $6.21, \mathrm{~s}$ & C-5, C-7, C-10 \\
\hline 7 & 159.9, & $\mathrm{C}$ & & \\
\hline 8 & 105.1, & $\mathrm{C}$ & & \\
\hline 9 & 152.8, & C & & \\
\hline 10 & 105.1, & $\mathrm{C}$ & & \\
\hline $1^{\prime}$ & 126.2, & $\mathrm{C}$ & & \\
\hline $2^{\prime} / 6^{\prime}$ & 129.1, & $\mathrm{CH}$ & 7.93, d (9.0) & $\mathrm{C}-2, \mathrm{C}-4^{\prime}$ \\
\hline $3^{\prime} / 5^{\prime}$ & 118.2, & $\mathrm{CH}$ & $7.27, \mathrm{~d}(9.0)$ & $\mathrm{C}-1^{\prime}, \mathrm{C}-4^{\prime}$ \\
\hline $4^{\prime}$ & 162.1, & $\mathrm{C}$ & & \\
\hline \multicolumn{5}{|c|}{$\alpha$-2,6-dideoxy-5-hydroxy-ribo-hexopyranoside } \\
\hline $1^{\prime \prime}$ & 64.5 & $\mathrm{CH}$ & 5.39 , dd $(5.0,1.5)$ & $\begin{array}{l}\text { C-7, C-8, C-9, } \\
\text { C-3", C-5" }\end{array}$ \\
\hline $2^{\prime \prime}$ & 37.4, & $\mathrm{CH}_{2}$ & $\begin{array}{l}2.48(\text { ddd, } 14.7,5.0,3.6) ; \\
2.30(\text { ddd, } 14.7,1.5,2.2)\end{array}$ & \\
\hline $3^{\prime \prime}$ & 67.0 & $\mathrm{CH}$ & $4.14 \mathrm{~m}$ & \\
\hline $4^{\prime \prime}$ & 73.6, & $\mathrm{CH}$ & $3.66, \mathrm{~d}(4.5)$ & $\mathrm{C}-6^{\prime \prime}$ \\
\hline $5^{\prime \prime}$ & 102.4, & $\mathrm{C}$ & & \\
\hline $6^{\prime \prime}$ & 25.7, & $\mathrm{CH}_{3}$ & $1.63, \mathrm{~s}$ & $\begin{array}{l}\mathrm{C}-7, \mathrm{C}-4^{\prime \prime}, \mathrm{C}- \\
5^{\prime \prime}\end{array}$ \\
\hline \multicolumn{5}{|c|}{$\beta$-D-glucose } \\
\hline $1^{\prime \prime \prime}$ & 101.7, & $\mathrm{CH}$ & $5.04, \mathrm{~d}(7.4)$ & \\
\hline $2^{\prime \prime \prime}$ & 74.8, & $\mathrm{CH}$ & $3.49^{a}$ & $C-3^{\prime \prime \prime}$ \\
\hline $3^{\prime \prime \prime}$ & 77.9, & $\mathrm{CH}$ & $3.49^{a}$ & $C-2^{\prime \prime \prime}, C-4^{\prime \prime \prime}$ \\
\hline $4^{\prime \prime \prime}$ & 71.2, & $\mathrm{CH}$ & $3.40^{a}$ & C-3"', C-5"' \\
\hline $5^{\prime \prime \prime}$ & 78.3, & $\mathrm{CH}$ & $3.49^{a}$ & C-3"', C- $4^{\prime \prime \prime}$ \\
\hline $6^{\prime \prime \prime}$ & 62.5 & $\mathrm{CH}_{2}$ & $\begin{array}{l}3.91, \mathrm{dd}(12.1,2.4) ; 3.71 \mathrm{dd} \\
\quad(12.1 ; 5.5)\end{array}$ & $C-5^{\prime \prime \prime}$ \\
\hline
\end{tabular}

\section{EXPERIMENTAL SECTION}

General Experimental Procedures. Optical rotations were determined using a PerkinElmer 241 polarimeter $\left(589 \mathrm{~nm}, 20^{\circ} \mathrm{C}\right)$. 
Table 4. Free Radical Scavenging Properties Obtained with the DPPH Method of the Crude Extract, Fractions, and Compounds from Serjania marginata

$\begin{array}{lc} & \mathrm{IC}_{50}\left(\mu \mathrm{g} \mathrm{mL}^{-1}\right) \\ \mathrm{EE} & 69.6 \\ \mathrm{~A} & 397.6 \\ \mathrm{~B} & 196.2 \\ \mathrm{C} & 42.8 \\ \text { cassiaoccidentalin A (2) } & -{ }^{a} \\ \text { tetrastigma B (3) } & - \\ \text { gallic acid } & 8.42 \\ \text { proanthocyanidin A-1 }^{b} & \\ \text { proanthocyanidin A-2 }^{b} & 8.55 \\ \text { cinnamtannin B-1 }^{c} & 9.71 \\ \end{array}$

$a_{(-)}$did not show free radical scavenging properties at concentrations $\leq 20 \mu \mathrm{g} \mathrm{mL}{ }^{-1}$. ${ }^{b}$ Value reported by Zhang and co-workers. ${ }^{47}{ }^{c}$ Value reported by Idowu and co-workers. ${ }^{29}$

UV spectra were recorded on a Jasco V-630 spectrophotometer. 1D and 2D NMR spectra were recorded on an Agilent 600 DD2 spectrometer and an Agilent $500 \mathrm{DD} 2$ spectrometer equipped with a 5 $\mathrm{mm}{ }^{1} \mathrm{H}\left\{{ }^{15} \mathrm{~N}-{ }^{31} \mathrm{P}\right\}$ PFG high-field inverse detection z-gradient probe. ${ }^{1} \mathrm{H}(599.772 \mathrm{MHz})$ and ${ }^{13} \mathrm{C}(125.666 \mathrm{MHz})$ NMR spectra were recorded in pyridine- $d_{5}$ and methanol- $d_{4}$ at $25{ }^{\circ} \mathrm{C}$. Chemical shifts are given on the $\delta$ scale and are referenced to residual pyridine $\left(\delta_{\mathrm{H}} 8.70\right.$, $7.55,7.18$ and $\left.\delta_{\mathrm{C}} 149.84,135.50,123.48\right)$ or methanol $\left(\delta_{\mathrm{H}} 3.30\right.$ and $\delta_{\mathrm{C}}$ 49.00). The Varian pulse sequence with a gradient was applied, and all 2D spectra, except for HMBC spectra of compound 4, were recorded in the phase-sensitive mode. Exact masses were measured on a UPLCQTOF ESI (Waters Synapt G2, Manchester, UK) HRESI-TOFMS instrument. Mass spectra were recorded in negative or positive ion mode in the range $m / z 100-2000$ with a mass resolution of 20000 and an acceleration voltage of $0.7 \mathrm{kV}$. The solvents used for the preparation of extracts and chromatographic fractionation were purchased from Prolabo VWR. Silica $60 \mathrm{~F}_{254}$ TLC plates (Merck) were used to monitor the isolation process. Preparative silica gel TLC (Merck, $0.25 \mathrm{~mm}$ ) was used to purify some of the flavonoid fractions. Compounds were visualized under $\mathrm{UV}_{254 / 366}$ light and by spraying with $\mathrm{H}_{2} \mathrm{SO}_{4} / \mathrm{H}_{2} \mathrm{O} / \mathrm{HOAc}$ (4:16:80 v/v/v). Sephadex LH-20 (SigmaAldrich) and Kieselger 60 silica gel $(200-60 \mu \mathrm{m}$, Merck) were used for column chromatography. HPLC separations were carried out on a Merck Hitachi system equipped with a LaChrom (L-2490) refractive index detector and an analytical Phenomenex Gemini $\mathrm{C}_{18}$ column (4.6 $\times 250 \mathrm{~mm}$, i.d) in isocratic mode.

Plant Material. Leaves of Serjania marginata Casar. were collected in February 2011 in an area of Cerrado located at a latitude of $21^{\circ} 59^{\prime} 41.8^{\prime \prime} \mathrm{S}$, a longitude of $55^{\circ} 19^{\prime} 24.9^{\prime \prime} \mathrm{W}$, and an altitude of $429 \mathrm{~m}$ in Dourados, Mato Grosso do Sul, Brazil. The plant was identified by Arnildo Pott, and a voucher specimen (no. 41054) has been deposited at the Herbarium of the Federal University of the Mato Grosso do Sul, Brazil.

Extraction and Isolation. The dried leaves $(500 \mathrm{~g})$ were extracted successively by percolation at room temperature with $\mathrm{EtOH} / \mathrm{H}_{2} \mathrm{O}$ $(7: 3, v / v)$. The ethanolic extract was filtered, concentrated under vacuum at approximately $40{ }^{\circ} \mathrm{C}$, and lyophilized to yield $163 \mathrm{~g}(33 \%)$ of the powdered extract. The crude extract $(5 \mathrm{~g})$ was suspended in $\mathrm{H}_{2} \mathrm{O} / n-\mathrm{BuOH}(3: 7, \mathrm{v} / \mathrm{v})$ and then extracted with $n$-BuOH. The solvent was removed to give $3.7 \mathrm{~g}(74 \%)$ of $n-\mathrm{BuOH}$ extract. A sample of the $n-\mathrm{BuOH}$ extract $(1.2 \mathrm{~g})$ was purified on a Sephadex LH-20 column $(4 \times 300 \mathrm{mg})$ with $\mathrm{MeOH}$ as eluent to give three principal fractions: A $(0.420 \mathrm{~g}, 35 \%), \mathrm{B}(0.299 \mathrm{~g}, 25 \%)$, and C (0.222 g, 18\%). Fraction A was chromatographed on silica gel $\mathrm{CHCl}_{3} / \mathrm{MeOH}(80: 20$ and 75:25) to give 3-O-D- $\beta$-glucopyranosylsitosterol $(7 \mathrm{mg})$ and three further fractions, which were purified by HPLC on an analytical $\mathrm{C}_{18}$ column $(1 \mathrm{~mL} / \mathrm{min})$ with acetone $/ \mathrm{H}_{2} \mathrm{O}(6: 4)$ as the mobile phase to give oleanolic acid 3-O- $\alpha$-L-rhamnopyranosyl $(1 \rightarrow 2)[\beta$-D- glucopyranosyl $(1 \rightarrow 4)]-\alpha$-L-arabinopyranoside $(2 \mathrm{mg})$, pulsatilla saponin D (5 mg), compound 1 (20 mg), and salzmannianoside B (2 $\mathrm{mg}$ ). Fraction B was chromatographed on silica gel $\mathrm{CHCl}_{3} / \mathrm{MeOH} /$ $\mathrm{H}_{2} \mathrm{O}(65: 30: 5)$ to give quercetin 3-O- $\alpha$-L-rhamnopyranoside (6 mg), epicatechin $(10 \mathrm{mg})$, and two further fractions, the first of which was purified by preparative $\mathrm{Si}$ gel TLC $\mathrm{CHCl}_{3} / \mathrm{MeOH} / \mathrm{H}_{2} \mathrm{O}(65: 30: 5)$ to afford apigenin 6-C- $\beta$-boivinopyranosyl-7-O- $\beta$-D-glucopyranoside (2 $\mathrm{mg}$ ), apigenin $6-C$ - $[2-O-\alpha$-L-rhamnopyranosyl $(1 \rightarrow 2)]-\beta$-D-xylopyranoside $(1 \mathrm{mg})$, and compound $4(0.7 \mathrm{mg})$. The second fraction was purified by HPLC on an analytical column $(1 \mathrm{~mL} / \mathrm{min})$ with $\mathrm{MeOH} /$ $\mathrm{H}_{2} \mathrm{O}$ (45:55) as the mobile phase to afford cassiaoccidentalin A (2) $(10 \mathrm{mg})$ and tetrastigma B (3) $(4 \mathrm{mg})$. Fraction $C$ was purified by HPLC on a semipreparative $\mathrm{C}_{18}$ column $(2 \mathrm{~mL} / \mathrm{min})$ with $\mathrm{MeOH} /$ $\mathrm{H}_{2} \mathrm{O}$ (4:6) acidified with $0.1 \%$ HOAc as the mobile phase to afford proanthocyanidins A-1 $(8 \mathrm{mg})$ and A-2 $(9 \mathrm{mg})$ and cinnamtannin B-1 (17 mg).

Acid Hydrolysis of Fraction A. Fraction A $(30 \mathrm{mg})$ was heated under reflux in $1 \mathrm{~N} \mathrm{HCl}(5 \mathrm{~mL})$ for $3 \mathrm{~h}$. The solution was extracted with EtOAc. The aqueous layer, which contained the sugars, was neutralized with Amberlite IR-45 ( $\mathrm{OH}^{-}$form). The sample $(19 \mathrm{mg}$ ) was purified by preparative $\mathrm{Si}$ gel TLC $\left(\mathrm{CH}_{2} \mathrm{Cl}_{2} / \mathrm{MeOH} / \mathrm{H}_{2} \mathrm{O}\right.$, 50:25:5) to afford rhamnose $\left[0.9 \mathrm{mg}, R_{f}=0.39,[\alpha]^{20}{ }_{\mathrm{D}}+6(c 0.09\right.$, $\left.\left.\mathrm{H}_{2} \mathrm{O}\right)\right]$; arabinose $\left[2 \mathrm{mg}, R_{f}=0.30,[\alpha]^{20}{ }_{\mathrm{D}}+8\left(c 0.2, \mathrm{H}_{2} \mathrm{O}\right)\right]$; and glucose $\left[1.7 \mathrm{mg}, R_{f}=0.23,[\alpha]^{20}{ }_{\mathrm{D}}+22\left(c 0.17, \mathrm{H}_{2} \mathrm{O}\right)\right]$, which were identified by comparison with authentic samples.

Acid Hydrolysis of Fraction B. Fraction B (23 mg) was heated under reflux in $1 \mathrm{~N} \mathrm{HCl}(2 \mathrm{~mL})$ for $1 \mathrm{~h}$. The mixture was allowed to cool and was centrifuged. The supernatant, which contained the sugars, was neutralized with Amberlite IR-45 $\left(\mathrm{OH}^{-}\right.$form $)$and concentrated. The sample $(11 \mathrm{mg})$ was purified by preparative $\mathrm{Si}$ gel TLC $\left(\mathrm{CHCl}_{3} / \mathrm{MeOH} / \mathrm{H}_{2} \mathrm{O}, 65: 30: 5\right)$ to afford rhamnose $\left[4 \mathrm{mg}, R_{f}=\right.$ $\left.0.35,[\alpha]^{20}{ }_{D}+27\left(c 0.15, \mathrm{H}_{2} \mathrm{O}\right)\right]$ and glucose $\left[0.9 \mathrm{mg}, R_{f}=0.15,[\alpha]_{\mathrm{D}}^{20}\right.$ $\left.+17\left(c 0.09, \mathrm{H}_{2} \mathrm{O}\right)\right]$, which were identified by comparison with authentic samples.

Serjanioside $D$ (1): amorphous, white powder; $[\alpha]^{20}{ }_{D}+1(c$ l 0.2 , $\mathrm{MeOH}) ;{ }^{1} \mathrm{H}$ NMR (pyridine- $d_{5}, 600 \mathrm{MHz}$ ) and ${ }^{13} \mathrm{C}$ NMR (pyridine$d_{5}, 125 \mathrm{MHz}$ ), see Table 1; HRESIMS $m / z 1027.5475[\mathrm{M}-\mathrm{H}]^{-}$ (calcd for $\mathrm{C}_{52} \mathrm{H}_{84} \mathrm{O}_{20}, 1027.5478$ ).

Serjanone $A$ (4): amorphous, yellow powder; $[\alpha]^{20}{ }_{\mathrm{D}}+17$ (c 0.1 , $\mathrm{MeOH}) ; \mathrm{UV} \lambda_{\max }(\log \varepsilon) 275$ (3.77), $320(\mathrm{sh})(3.67) \mathrm{nm} ;{ }^{1} \mathrm{H}$ NMR $\left(\mathrm{MeOH}-d_{4}, 600 \mathrm{MHz}\right)$ and ${ }^{13} \mathrm{C} \mathrm{NMR}\left(\mathrm{MeOH}-d_{4}, 125 \mathrm{MHz}\right)$, see Table 3; HRESIMS $m / z 561.1610[\mathrm{M}+1]^{+}$(calcd for $\mathrm{C}_{27} \mathrm{H}_{29} \mathrm{O}_{13}$, 561.1608); MS-MS ESI-pos (561 $(\mathrm{M}+\mathrm{H})) 399(\mathrm{M}-\mathrm{glc}+\mathrm{H}) ; 381$ $\left(\mathrm{M}-\mathrm{glc}-\mathrm{H}_{2} \mathrm{O}+\mathrm{H}\right) ; 325\left(\mathrm{M}-\mathrm{glc}-\mathrm{C}_{3} \mathrm{H}_{6} \mathrm{O}_{2}+\mathrm{H}\right) ; 297(\mathrm{M}-\mathrm{glc}$ $\left.-\mathrm{C}_{4} \mathrm{H}_{6} \mathrm{O}_{3}+\mathrm{H}\right)$; ESI-neg $(605(\mathrm{M}+\mathrm{HCOOH}-\mathrm{H})) 559(\mathrm{M}-\mathrm{H})$; $485\left(\mathrm{M}-\mathrm{C}_{3} \mathrm{H}_{6} \mathrm{O}_{2}-\mathrm{H}\right) ; 457\left(\mathrm{M}-\mathrm{C}_{4} \mathrm{H}_{6} \mathrm{O}_{3}-\mathrm{H}\right) ; 397(\mathrm{M}-\mathrm{glc}-$ $\mathrm{H}) ; 323\left(\mathrm{M}-\right.$ glc $\left.-\mathrm{C}_{3} \mathrm{H}_{6} \mathrm{O}_{2}-\mathrm{H}\right) ; 295\left(\mathrm{M}-\right.$ glc $\left.-\mathrm{C}_{4} \mathrm{H}_{6} \mathrm{O}_{3}-\mathrm{H}\right)$.

DPPH Photometric Assay. The antioxidant activities of $70 \%$ ethanol extracts of the fractions and compounds 2 and 3 were evaluated. Concentrations of $6.25,12.5,50,100$, and $200 \mu \mathrm{g} \mathrm{mL}^{-1}$ were tested for EE and fractions, in 96-well plates, in order to identify the concentration for $50 \%$ inhibition $\left(\mathrm{IC}_{50}\right)$ for each sample. Thus, concentrations in the range 20 to $90 \mu \mathrm{g} \mathrm{mL}^{-1}$ for EE, 100 to $700 \mu \mathrm{g}$ $\mathrm{mL}^{-1}$ for fraction $\mathrm{A}, 100$ to $400 \mu \mathrm{g} \mathrm{mL}^{-1}$ for fraction $\mathrm{B}$, and 10 to 70 $\mu \mathrm{g} \mathrm{mL} \mathrm{m}^{-1}$ for fraction $\mathrm{C}$ were tested to obtain the $\mathrm{IC}_{50}$. Pure compounds were tested at 0.625 to $20 \mu \mathrm{g} \mathrm{mL}^{-1}$. The samples were dissolved in $\mathrm{MeOH} / \mathrm{H}_{2} \mathrm{O}$ (8:2), and $0.2 \mathrm{~mL}$ of a $0.004 \% \mathrm{DPPH}$ solution in $\mathrm{MeOH} / \mathrm{H}_{2} \mathrm{O}(8: 2)$ was added to $0.02 \mathrm{~mL}$ of the sample solutions at different concentrations. The mixtures were allowed to react at room temperature. After $30 \mathrm{~min}$ the absorbance values were measured at $517 \mathrm{~nm}$ using a UV-vis spectrophotometer (BioTek model Epoch). The blank consisted of $0.2 \mathrm{~mL}$ of DPPH and $0.02 \mathrm{~mL}$ of $\mathrm{MeOH} / \mathrm{H}_{2} \mathrm{O}$ (8:2). Standard solutions of gallic acid were prepared and analyzed under identical conditions. The results are expressed according to the percentage of inhibition, and this was calculated using the following equation: $\Delta 0 \%=100 \times\left(A_{0}-A\right) / A_{0}$, where $\Delta 0 \%$ is the percentage of sequestration, $A_{0}$ is the absorbance of the blank, and $A$ is the absorbance of the sample after a reaction time of $30 \mathrm{~min}$. The $\mathrm{IC}_{50}$ value was calculated by regression analysis in which concentrations 
tested versus percentage of sequestration are used. All tests were carried out in triplicate.

\section{ASSOCIATED CONTENT}

\section{S Supporting Information}

HRESIMS, 1D and 2D NMR spectra for compounds 1 and 4. ${ }^{1} \mathrm{H}$ NMR spectra of compounds 2 and $3\left(\mathrm{MeOH}-d_{4}\right) .{ }^{1} \mathrm{H}$ NMR data for apigenin $6-C$-[2-O- $\alpha$-L-rhamnopyranosyl $(1 \rightarrow 2)]-\beta$-Dxylopyranoside that have not been reported to date. This material is available free of charge via the Internet at http:// pubs.acs.org.

\section{AUTHOR INFORMATION}

\section{Corresponding Author}

*Tel: +34 956 012770. Fax: +34 956 016193. E-mail: famacias@uca.es.

\section{Notes}

The authors declare no competing financial interest.

\section{ACKNOWLEDGMENTS}

The authors thank the Sao Paulo State Research Foundation (FAPESP) (grant 2009/52237-9 to W.V. and grant 2011/ 08880-4 to S.C.H.V.) and the Coordination for the Improvement of Higher Education Personnel (CAPES, PDSE-17995/ 12-4 to S.C.H.V.) for funding and fellowships. This research was supported by the Ministerio de Economía y Competitividad (MINECO) (Project AGL2013-42238-R) and Consejería de Economía Innovación y Ciencia, Junta de Andalucia (Project AGR-5822-2011).

\section{REFERENCES}

(1) Souza, V. C.; Lorenzi, H. Botânica Sistemática: Guia Ilustrado para Identificação das Famílias de Fanerógmas Nativas e Exóticas no Brasil, baseado em APG III; Instituto Plantarum: Nova Odessa, 2013; pp 454-459.

(2) Sparg, S. G.; Light, M. E.; Van Staden, J. J. Ethnopharmacol. 2004, 94, 219-243.

(3) Lima, M. R. F.; Luna, J. S.; Santos, A. F.; Andrade, M. C. C.; Sant'Ana, A. E. G.; Genet, J. P.; Marquez, B.; Neuville, L.; Moreau, N. J. Ethnopharmacol. 2006, 105, 137-147.

(4) Cardoso, C. A. L.; Coelho, R. G.; Honda, N. K.; Pott, A.; Pavan, F. R.; Leite, C. Q. F. Braz. J. Pharm. Sci. 2013, 49, 775-782.

(5) Moreira, R. P. M.; Batista, C. S.; Guarim Neto, G. Flovet 2013, 5, $1-21$.

(6) Gomig, F.; Pietrovski, E. F.; Guedes, A.; Dalmarco, E. M.; Calderari, M. T.; Guimarães, C. L.; Pinheiro, R. M.; Cabrini, D. A.; Otuki, M. F. J. Ethnopharmacol. 2008, 118, 220-224.

(7) Arruda, A. P. C. C. B. N.; Coelho, R. G.; Honda, N. K.; Ferrazoli, C.; Pott, A.; Hiruma-Loma, C. A. J. Med. Food. 2009, 12, 1411-1415.

(8) Mesquita, M. L.; Desrivot, J.; Bories, C.; Fournet, A.; Paula, J. E.; Grellier, P.; Espindola, L. S. Mem. Inst. Oswaldo Cruz 2005, 100, 783787.

(9) Rodrigues, A. M. S.; Paula, J. E.; Degallier, N.; Molez, J. F.; Espíndola, L. S. J. Am. Mosq. Control Assoc. 2006, 22, 314-317.

(10) Napolitano, D. R.; Mineo, J. R.; De Souza, M. A.; De Paula, J. E.; Espondola, L. S.; Espindola, F. S. J. Ethnopharmacol. 2005, 99, 37-41.

(11) Ekabo, O. A.; Farnsworth, N. R.; Henderson, T. O.; Mao, G.; Mukherjee, R. J. Nat. Prod. 1996, 59, 431-435.

(12) David, J. P.; Meira, M.; David, J. M.; Brandão, H. N.; Branco, A.; Agra, M. F.; Barbosa, M. R. V.; Queiroz, L. P.; Giulietti, A. M. Fitoterapia 2007, 78, 215-218.

(13) Polanco-Hernández, G.; Escalante-Erosa, F.; García-Sosa, K.; Acosta-Viana, K.; Chan-Bacab, M. J.; Sagua-Franco, H.; González, J.; Osorio-Rodríguez, L.; Moo-Puc, R. E.; Peña-Rodríguez, L. M. Parasitol. Res. 2012, 110, 31-35.
(14) Silva, J. L. V.; Carvalho, V. S.; Silva, F. L.; Barbosa-Filho, J. M.; Rigoni, V. L. S.; Nouailhetas, V. L. A. Pharmacologyonline 2012, 1, $22-$ 26.

(15) Teixeira, J. R. M.; Lapa, A. J.; Souccar, C.; Valle, J. R. J. Ethnopharmacol. 1984, 10, 311-318.

(16) Chávez, M. I.; Delgado, G. Tetrahedron 1994, 50, 3869-3878.

(17) Périco, L. L. Avaliação dos Mecanismos de Ação Envolvidos na Atividade Antiulcerogênica de Serjania marginata frente à Doença Ulcerosa Péptica Experimental. MSc. Dissertação; UNESP: Araraquara, SP, 2014.

(18) Joly, C. A.; Haddad, C. F. B.; Verdade, L. M.; Oliveira, M. C.; Bolzani, V. S.; Berlink, R. G. S. Rev. USP 2011, 89, 114-133.

(19) Montruchio, D. P.; Miguel, O. G.; Miguel, M. D.; Monache, F. D.; Carvalho, J. L. S. Visão Acad. 2005, 6, 48-52.

(20) Kang, S. S. Arch. Pharma Res. 1989, 12, 42-27.

(21) Schenkel, P.; Werner, W.; Schulte, K. E. Planta Med. 1991, 57, 463-467.

(22) Santos, P. M. L.; Schripsema, J.; Kuster, R. M. Rev. Bras. Farmacogn. 2005, 15, 321-325.

(23) Lôbo, L. T.; Castro, K. C. F.; Arruda, M. S. P.; Silva, M. N.; Arruda, A. C.; Müller, A. H.; Arruda, G. N. S.; Santos, A. S.; Filho, A. P. S. S. Quím. Nova 2008, 31, 493-497.

(24) Hatano, T.; Mizuta, S.; Ito, H.; Yoshida, T. Phytochemistry 1999, $52,1379-1383$.

(25) Jin, M.-N.; Shi, G.-R.; Tang, S.-A.; Nan-Qin; Wei Qiao; Duan, H.-Q. Fitoterapia 2013, 90, 240-246.

(26) Zhu, D.; Yang, J.; Deng, X.-T.; Lai, M.-X.; Wang, Q. Chin. J. Nat. Med. 2009, 7, 184-186.

(27) Takeda, Y.; Okada, Y.; Masuda, T.; Hirata, E.; Shinzato, T.; Otsuka, H. Phytochemistry 2004, 463-468.

(28) Lou, H.; Yamazaki, Y.; Sasaki, T.; Uchida, M.; Tanaka, H.; Oka, S. Phytochemistry 1999, 51, 297-308.

(29) Idowu, T. O.; Ogundaini, A. O.; Salau, A. O.; Obuotor, E. M.; Bezabih, M.; Abegaz, B. M. Phytochemistry 2010, 71, 1092-1098.

(30) Gheysen, K.; Mihai, C.; Conrath, K.; Martins, J. C. Chem.-Eur. J. 2008, 14, 8869-8878.

(31) Macías, F. A.; Guerra, J. O.; Simonet, A. M.; Nogueiras, C. M. Magn. Reson. Chem. 2007, 45, 615-620.

(32) Fan, L.; Lu, J.; Beibei, X.; Song, G.; Hongfen, Z.; Runxiang, L. Helv. Chim. Acta 2010, 93, 58-64.

(33) Hai, W.; Hua, C.; Mei, Z.; Yi, W.; Liangjian, H.; Haifeng, T.; Xiangrong, T. Fitoterapia 2012, 83, 759-764.

(34) Davoust, D.; Massias, M.; Molho, D. Org. Magn. Reson. 1980, $13,218-219$.

(35) Markham, K. R.; Mues, R.; Stoll, M.; Zinsmeister, H. D. Z. Naturforsch. 1987, 42c, 1039-1042.

(36) Liu, H. M.; Sato, Y.; Tsuda, Y. Chem. Pharm. Bull. 1993, 41, 491-501.

(37) Liu, H. M.; Tsuda, Y. Chem. Pharm. Bull. 1996, 44, 80-87.

(38) Xu, F.; Wang, C.; Yang, L.; Luo, H.; Fan, W.; Zi, C.; Dong, F.; Hu, J.; Zhou, J. Food Chem. 2013, 136, 94-99.

(39) Rale, M.; Schneider, S.; Sprenger, G. A.; Samland, A. K.; Fessner, W. D. Chem.-Eur. J. 2011, 17, 2623-2632.

(40) Shen, C. C.; Cheng, J. J.; Lay, H. L.; Wu, S. Y.; Ni, C. L.; Teng, C. M.; Chen, C. C. J. Nat. Prod. 2012, 75, 198-201.

(41) Furuta, T.; Kimura, T.; Kondo, S.; Mihara, H.; Wakimoto, T.; Nuyura, H.; Tsuji, K.; Tanaka, K. Tetrahedron 2004, 60, 9375-9379.

(42) PCMODEL 9.2; Serena Software: Bloomington, IN, 2006.

(43) Bafna, P. A.; Balaraman, R. J. Ethnopharmacol. 2004, 90, 123127.

(44) Fernandes, R. S.; Costa, T. R.; Marcussi, S.; Bernardes, C. P.; Menaldo, D. L.; Gonzaléz, R.; Pereira, P. S.; Soares, A. M. J. Venom. Anim. Toxins Incl. Trop. Dis. 2011, 17, 85-93.

(45) La Casa, C.; Villegas, I.; Alarcón de La Lastra, C.; Motilva, V.; Martín Calero, M. J. J. Ethnopharmacol. 2000, 71, 45-53.

(46) Rastogi, L.; Patnaik, G. K.; Diskshit, M. Pharmacol. Res. 1998, $38,125-132$.

(47) Zhang, H.; Ye, R.; Yang, Y.; Ma, C. J. Agric. Food Chem. 2013, $61,8814-8820$. 
(48) Scherer, R.; Godoy, H. T. Food Chem. 2009, 112, 654-658.

(49) Ramírez, R. O.; Roa, C. C. Clin. Hemorheol. Microcirc. 2003, 29, 253-261.

(50) Prado, L. C.; Silva, D. B.; Oliveira-Silva, G. L.; Hiraki, K. R. N.; Canabrava, H. A. N.; Bispo-da-Silva, L. B. Biol. Pharm. Bull. 2014, 37, $722-730$.

(51) Vasconcelos, P. C. P.; Andreo, M. A.; Vilegas, W.; Hiruma-Lima, C. A.; Pellizon, C. H. J. Ethnopharmacol. 2010, 131, 146-153. 